Article

\title{
Crank up the Feminism: Poetic Inquiry as Feminist Methodology
}

\section{Sandra L. Faulkner}

Women's Gender, and Sexuality Studies, Bowling Green State University, Bowling Green, OH 43403, USA; sandraf@bgsu.edu

Received: 23 June 2018; Accepted: 17 August 2018; Published: 23 August 2018

\begin{abstract}
In this autoethnographic essay, the author argues for the use of poetic inquiry as a feminist methodology by showing her use of poetry as research method during the past 13 years. Through examples of her poetic inquiry work, the author details how poetry as research offers Women's, Gender, and Sexuality Studies scholars a means of doing, showing, and teaching embodiment and reflexivity, a way to refuse the mind-body dialectic, a form of feminist ethnography, and a catalyst for social agitation and change. The author uses examples of her ethnographic poetry that critique middle-class White motherhood, address the problems of White feminism, and reflects the nuances of identity negotiation in research and personal life to show the breadth of topics and approaches of poetic inquiry as feminist research practice and feminist pedagogy.
\end{abstract}

Keywords: autoethnography; embodiment; feminist methodology; feminist research practice; poetry; poetic inquiry; Women's Gender, and Sexuality Studies

\section{Crank up the Feminism}

We declare feminist law

like shrews in heat

dial up the belligerent bass

from the front seat.

We do our hair in rosy rage

smear righteous red on our cheeks

as we pull on our combat best dress

the anti-patriarchy patrol in suffragette white.

The usual boys have no idea

what to do as we shank

the good girl in the mirror:

You're all lesbians now, America!

Our art bleeds down our legs

pools like rubies on piles of rubble

that can't be swept under rugs:

our rage refuses to ride shotgun.

We skip the protest and go

right for the throat, steal bologna

sandwiches from the Boy Scout's

tent yawping, You want to see rogue? 
We snap the elastic in your pants, show up five minutes late with wet hair and chipped nails, hit send without proofreading:

you can type your own template as we crush the control panel throttle up the appropriate volume smashing the baby over your knees. (Faulkner 2018a)

Embodiment is an important concept in feminist theory, research, and praxis. Feminist poetry offers a means of doing, showing, and teaching embodied inquiry. I begin this essay with a poem I wrote in response to Alex Ruth Bertulis-Fernandes's art piece called 'DIAL DOWN THE FEMINISM', which consists of a photo of a control panel with a dial and two volume settings-complicit in my own dehumanization and raging feminist-with the dial turned to raging feminist (Grasso 2018). Alex's art professor told her to dial down the feminism in her work, and Alex responded with feminist art. As I wrote my ekphrastic poetic response to Bertulis-Fernandes's work, I thought of all of ways I've been told in my life and career that "my feminism has ruined me," that my work is too critical, that I should be the "Good White Girl," that I have destroyed others' altruistic visions of motherhood, and that I shouldn't put that "poetry stuff" on my vitae (Faulkner 2016a). I am a feminist ethnographer and scholar who studies close relationships and uses poetic inquiry as a way to show the messy work of living a feminist life (Ahmed 2017), being a feminist scholar and teacher, being a feminist partner and mother, and doing feminist relationship research.

In this essay, I take an autoethnographic approach to argue that poetic inquiry can be a feminist research methodology because of what poetry can do and be. We can use poetry in our research, teaching, and praxis as feminist scholars. I show you my evolution from a traditional qualitative researcher to an Arts-Based Research Practitioner who uses poetry in teaching as well as poetry as a feminist research method. "Poetic inquiry is the use of poetry crafted from research endeavors, either before project analysis, as a project analysis, and/or poetry that is part of or that constitutes an entire research project" (Faulkner 2017a, p. 210). I present my story to show how poetry can be a means of demonstrating embodiment and reflexivity, a way to refuse the mind-body dialectic, a form of feminist ethnography, and a catalyst for social agitation and change. I detail my use of ethnographic poetry that critiques middle-class White motherhood, addresses the problems with White feminism, and reflects the nuances of identity negotiation in research and personal life to show the breadth of topics and approaches of poetic inquiry as feminist research practice.

\section{Poetic Inquiry as Feminist Methodology}

I write poetry because I am a bad (BAD!) social scientist (Faulkner 2009). I study personal relationships; I am most interested in what relationships feel like and sound like and smell like more than how they function as some kind of analytic variable to be deconstructed. I believe in poetic truth(s) more than social science Truth punctuated with a capital T ... What I understand is that one can write poetry as social science. What I believe in is the value of poetry as relationship research. (Faulkner 2017b, p. 148)

I began using poetry in my teaching and research as a scholar of close relationships when I needed to talk about identity and communication in a more nuanced fashion and wanted to describe the physicality and emotionality of doing research (Faulkner 2005). In poetry, I show my embodiment as a feminist, as a scholar, as a teacher, and as a feminist scholar teacher who feels their way through research with mind AND body (see Ellingson 2017).

Poetry can help us see our relationships bleeding out, hemorrhaging from the invisible inside, spilling outside the neat axioms of theory. Poetry is theory. Poetry can have us experience 
the social structures and ruptures in situ as we read, as we listen, as we hold our breath waiting for the next line. Poetry is bandage and salve. Poetry lets me goodwill my secure cloak of citations, argue in verse that there is space for critical work and personal experience in the study of close relationships. (Faulkner 2017b, p. 149)

I have written poetry since childhood and often write poems when I am trying to make sense of difficult life experiences such as cancer and motherhood (e.g., Faulkner 2014a; Faulkner 2017d). Shortly after finishing my PhD when I was engaged in a project on LGBTQ Jewish identity (Faulkner and Hecht 2011), I merged my poetry with my social science training by presenting the narrative research as poetry (Faulkner 2006). "Writing poetry helped me recover from my training in graduate school and the numbing realities of academic writing. It helped me reclaim creativity and its rhythms" (Faulkner 2014a, p. xiii). I felt that the twists and turns in the research study, showing my reflexivity as a feminist scholar, and the bodily experience of doing and being a feminist ethnographer were best presented as poetry. I wrote the method's section of the work (Faulkner 2005) as a series of 6 poems to show the research story (see Richardson 1997), my subjective emotional processes, difficulties of identities in fieldwork, and the challenges of conducting interviews while being reflexive and conscious. In the poems, I was able to highlight how identities as researcher and participant were negotiated in situ. For example, the following poem about a participants' reaction to me as a researcher is a story a traditional method's section couldn't tell:

\section{I'm Not What Lisa Expected}

no blonde bunned hair

like the researcher in her mind,

like my second grade teacher, glasses,

but blue and stylish and young.

I'm 31 and old enough to teach, ask others about their identities,

though I have scant lines on face and vita, wear shirts without collars.

I talk as a friend-except those questions about being gay and Jewishas I shift, catch words with my recorder, camo cargo pants belie my worry with uniform.

Another participant claims I walk lesbianlike, confident stride and spiky cut hair, into her usual diner on 7th Avenue where we eat rice pudding like family. She knew who I was without my description5 feet 5 inches, red hair, short and sapphire spectacles-

How do I tell them that I live and flirt and fight with a man now, that my

ex-girlfriend calls me semi-straight and semi-gay and too interested in labels? (Faulkner 2005)

A method's section as poetry highlighted a different story-a not so neatly packaged story of how we negotiate our identities in the field. I longed to send the poem, Letter to the IRB from South Jersey, as a response to my Institutional Review Board instead of the typical template to ask for continued approval to talk with LGBTQ Jews about their identities and life. This epistolary poem let me use an intimate tone and talk about becoming friends with research participants, how I managed identity as 
a researcher and a human being, and the influences that life and values have on what I noticed and commented on in a research setting:

\section{Letter to the IRB from South Jersey}

Dear Institutional Review Board:

I know it has been a year, but I am still in the field.

The renewal form for study 11147 (Gay Jewish Identity)

is mostly complete. As usual, you provide too little

space, no more than 2 costly lines, so I append this letter.

Just in case. I considered your focused questions as I drove north, away from the tattooed gentiles in Cape May, the Jersey turnpike and the unctuous winter storm coating my Volkswagen.

I was nervous, had too tight a grip on the wheel. Unanticipated consequences of this research? I could skid under a trailer, the cybergreen Beetle with the German engineering I have admired since I was 15 , the "cool car, but one I shouldn't own," screeching part in pieces along with the German chocolate cake from the cooking school bakery in my stomach. My interviewee in Atlantic City bought it for us. He said on Saturdays the students sell goodies, cheap. If you go early. We drink his good coffee-not that dirty water from Jersey diners-in mustard luster ware cups from Czechoslovakia (I checked the bottom). As I listen to their stories, I drink too much crappy coffee, eat raisin toast with margarine, bagels and jelly, fruit plates with cottage cheese, listen to piped-in light favorites at their local diners. I rent space with food. Sometimes afterwards, we talk like friends. You know, we exchange book titles, share artwork and our secrets about relationships. I meet every Monday with Lesa, once participant, now friend, to eat bagels. Positive consequence, would you agree? Did I mention the car I drive to meet participants? Is this an unanticipated negative consequence? What about the consent form?

I know we have to cover our asses, but the signature line creeps me out, them signing their names on an official page like a hit list. I want to ask you these questions, even if they smack of academic drama. What they really want to know about me is not there, on your consent form. I have rewritten it: Bisexual of German/English/Scottish Ancestry who grew up in Atlanta with Yankee parents seeks LGBT Jews for conversation. Has experience with Jews.

They like to hear my stories of exes, mentors, all of the Jews in my life, why I'm interested in their lifework. I guess the personal connection. Sometimes, what really matters is this. (Faulkner 2005)

\section{Feminist Poetry and Embodiment}

After this first project, I began to see how poetry helped me create and sustain a reflexive research process and document my stumbles and growth as a researcher and a teacher. I use poetic inquiry in my feminist research and teaching to agitate for social change, to show embodiment and reflexivity, to collapse the false divide between body and mind, public and private, and as a feminist ethical practice. I use poetry as a feminist methodology to crank up the feminism. In a poetry manifesto (Faulkner 2017c), I made the claim that "the personal is poetry ... Poetry of personal experience is 
vital. Poetry has the power to highlight slippery identity-negotiation processes and present more nuanced views of marginalized and stigmatized identities, to demonstrate embodied experience and to be social research and autoethnography" (p. 93). I also discovered that using poetry in the classroom made for more engaged teaching practice; students responded to poetry, both their own and others.

Feminist scholars, women of color, and practitioners have been interested in embodiment, experiential knowledge and theories of the flesh for quite some time (Collins 2000; Moraga and Anzaldúa 1981); poetic inquiry and feminist poetry are examples of how we can engage in embodied inquiry to emphasize the importance of storytelling and narrative in the representation of knowledge and everyday experience. Poets can use their work to give voice to gendered experiences as a form of political activity and consciousness-raising (Reed [2005] 2013). Strine (1989) notes, "poetic discourse is quintessentially a site of personal and ideological struggle within the on-going cultural dialogue" (p. 26). Poetry as research method is one means to theorize using the body and to disavow the mind-body split still present in much academic work. Poetry lets us "come in through the backdoor with the feeling, the emotion, the experience. But if you start reflecting on that experience you can come back to the theory" (Moraga and Anzaldúa 1981, p. 263). Brady (2004) argues that poetry can return researchers back to their bodies and highlight how theory comes from our embodied experiences. "Meaning is made in that way, not found, and in its making it gets anchored in what appeals to the senses, the sensual, including bodies themselves" (p. 624).

I argue that poetic inquiry offers a feminist research methodology because of the focus on embodied experiences and attention to breath, line, form, and emotion-all things that speak to the body. More specifically, I contend that poetry as Women's, Gender, and Sexuality scholarship and praxis is a way to refuse the mind-body split and demonstrate embodiment. Feminist scholars and poets have been using poetry as a means to represent their bodily experiences. As Reed (Reed [2005] 2013) argued, "poetry is particularly well equipped to challenge crucial dichotomies: the separation of private and public spheres, and the split between emotion and intellect ... Poetry was theory. Poetry was feminist practice" (p. 89). For example, Adrienne Rich's Diving into the Wreck: Poems 1971-1972 and The School among the Ruins: Poems, 2000-2004 engage with a feminist ethics to show a radical feminist take on racism, identity, sexuality, and politics (Poetry Foundation 2012). Poetic inquiry and poetry are still feminist practice and theory. Reilly, Lee, Laux, and Robitaille (Reilly et al. 2018) used found poetry of women's experiences with breast cancer to describe their existential and posttraumatic growth experiences, because "poetry has the potential to uplift the human spirit to a vision of another's reality" (p. 21). The researchers transformed interviews into poetry as a means to evoke rich and meaningful experience of participants' voices.

Poetry in research is a way to tap into universality and radical subjectivity; the poet uses personal experience and research to create something from the particular, which becomes universal when the audience relates to, embodies, and/or experiences the work as if it were their own. (Faulkner 2017a, p. 210)

"Good poetry makes personal experience available to others by giving it an outward form" (Reed [2005] 2013, p. 86). In the pages that follow, I highlight my use of poetic inquiry as feminist methodology and praxis around issues of identity, motherhood, mothering, and Interpersonal Communication, and sexual harassment in the academy.

\section{Identity Work}

I offer examples in my own work of how poetic inquiry has helped me represent and understand identity negotiation in close relationships in a collaborative project on feminist identity in romantic relationships (Faulkner and Ruby 2015), as a feminist ethnographer living in Germany on sabbatical (Faulkner 2016b), and as a White feminist critiquing White Feminism (Faulkner and Squillante 2018). The use of poetry as a research method helped me accomplish goals of collaborative action, cultural critique and resistance. 
Poetry, in particular, makes me a better social scientist. When you read poetry, my poetry, I want you to do more than think about your own life; I want you to critique how social structures scaffold your experiences of relating. (Faulkner 2017b, p. 150)

Feminist identity in close relationships. Ruby and I (Faulkner and Ruby 2015) use collaborative autoethnography (CAE) and found poetry/poetic transcription as a feminist method to show how feminist identity in a romantic relationship influences relational discourse. The use of CAE speaks to feminist work because of the focus on personal experience, attention to reflexivity, and collaboration (Olesen 2005). This kind of dyadic collaborative work is an example of a feminist constitutive and critical approach to interpersonal communication scholarship (Manning and Kunkel 2015). Our use of found poetry from a year-long series of our email exchanges acted as a critique of traditional interpersonal communication research that typically focuses on variable analytic work and one dominant position.

We found the process of using academic research as an analysis tool an illumination of our relationship and the culture and context in which it existed; using our expertise and skill as poets and scholars demonstrates that poetic and scientific understandings of relationships can coexist. Academic discourse and romantic discourse can dialogue and potentially alter unproductive and harmful dominant discourse about romance. (Faulkner and Ruby 2015, p. 224)

We considered how personal identities—feminist, working class, bourgeois, academic-interacted with relational processes to create a relational identity that was contested as seen in this poetic transcription:

>>Bacon reminds me of the side of men I can't swallow.

my truck of love came

at you hard and fast

it crushed your intellectual Volkswagen beetle.

You didn't have your seatbelt

on tight enough

now you are fucked

i feel that way everyday

i got a big cranial woody for you

I want to unfold you

you feel bad i feel good

like that. not telling

i had a bucketful for you inside (p. 214)

Discourse equating feminist identity with intellect and feelings and love as connected to romance disallowed a comfortable fit for feminism in a relational culture that privileged embodied sensual experience:

the way that i feel about you

overshadows academic concepts like they don't even exist

my feelings towards you

transcend the conscious/intellectual world

my feelings are not

for grading or evaluation against technical, political or academic yardsticks

$\mathrm{i}$ understand the issue is how YOU feel not how I feel.

This relational identity was seen in poetic transcription and found poems that demonstrated antagonistic discourses between feminist ethics, individual identities, and romance narratives that contributed to a conflicted relational culture because of different meanings of intimacy. 
Multiple stigmatized identities. I used poetry to present the experiences of LGBTQ Jews in a project on negotiating multiple stigmatized identities (Faulkner 2006; Faulkner and Hecht 2011).

Because poetry defies singular definitions and explanations, it mirrors the slipperiness of identity, the difficulty of capturing the shifting nature of who we are and want to be, and resonates more fully with the way identity is created, maintained, and altered through our interacted narratives. (Faulkner 2009, p. 100)

My goal in this project was to be an ethnographer who uses ethnographic poetry as research to show the connection between researcher and participant's identities (Krizek 2003), a poet researcher who provokes emotional responses, and furthers theory through the use of poetic inquiry. Ethnographic poetry is "how the poet reflects on field experiences and reframes them through poetry to provide insight into specific cultures and definitions of the term culture ... by displaying writing about differences and similarities with no easy, determinate answers, and by engaging in the tension between community insiders/outsiders" (Faulkner 2009, p. 24). I wrote poems from interviews, observations, and field notes to embody the experience of being LGBTQ and Jewish in ways that pay attention to the senses and offer some narrative and poetic truths about the experience of multiple stigmatized identities. "Poetry can do what other forms of thinking cannot: approximate the actual flavor of life, in which subjective and objective become one, in which conceptual mind and the inexpressible presence of things become one" (Hirshfield 1997, p. 32). I argue that the use of poetry in this project further identity theories through poems that challenge stereotypes, confront prejudices, and add to the representation of LGBTQ Jews. The following poem presents the communication process of identity by portraying the reality of multiple and intersecting identities and differences in negotiation.

\section{Reconstructionist}

She thinks it's different now, and asks me how

I find the rallies, picnics, police, gay

lovers with youth who walk in open now.

She found no path, no help with the labels,

the parties of conservative newspapers

that print Jewish activist lesbian

as if boxes can contain her labors

to make Seders and new year with new kin.

Now she tells mom, keeps a job, says enough

and buys a house with oaks and shaded jade,

makes a minyan and trims a holly bough

with a Christian woman. The years they've made,

are like the book club books read together

for 12 years when they had nothing better.

Feminist Ethnographer. In Postcards from Germany (Faulkner 2016b), I composed a ethnographic chapbook consisting of poems, images, and sounds about my embodied experiences living, teaching, traveling, and studying in Germany on sabbatical as a feminist ethnographer. I used the chapbook form and the idea of atypical postcards to flaunt the false dichotomy between the domestic and public sphere, between the private and the public, and to show the interplay between power and difference.

Chapbooks represent a part of DIY culture and have been from inception, a medium for political action to a venue for avant-garde and new writers .... Contemporary iterations of chapbooks have been likened to DIY paperbacks and are popular again in the contemporary poetry world because of the production ease, path to other publications, and risk-taking in subject and/or style. They have changed from their past as a vehicle for the democratization of readership to a democratizing means of production for writers. (Faulkner 2016b) 
The postcard poems (see figures as follows) subvert the usual way we map trips and send the most picturesque parts to others for their consumption.

Gefühle in Deutsch Klasse (Feelings in German Class)

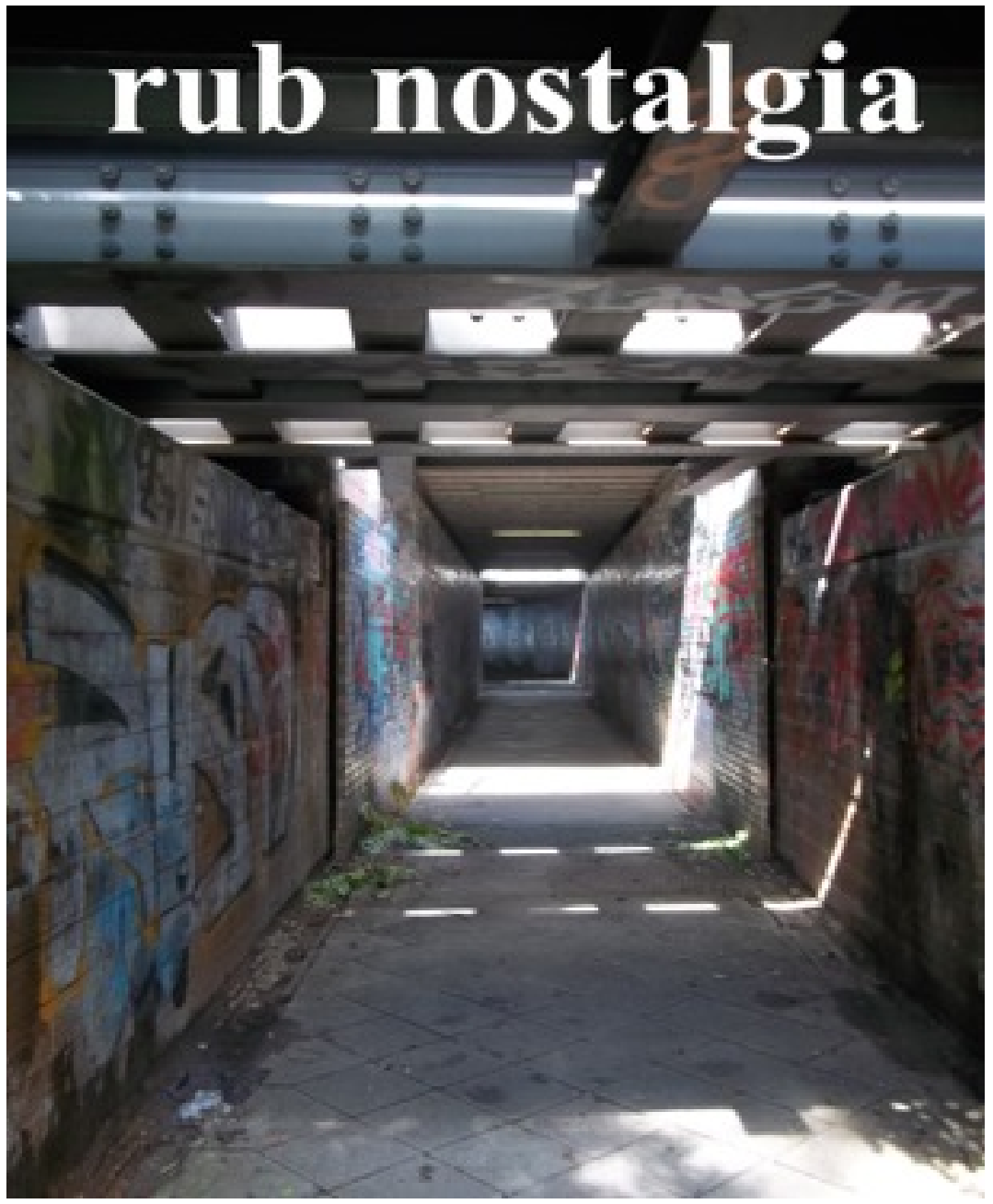

1. Die Trauer (The Sadness)

I have two weeks left und schon I miss Mannheim, my life, and get all like weepy American as I scratch plus and minus signs on notebook lines next to feelings when mein Lehrer asks, negativ oder positiv? I pen the Gestalt wrong, all scribbles up and down, and slash out the sad signs my German is not prima or tollor any other of my Lehrer's praise- but bad.

At least I'm getting the gloom out of my way rubbing the feelings of nostalgia over my notes in an efficient display, better than being a middle-aged mute und traurig like the first Deutsch als Fremdsprache class all in German -no comparing to English = I'll miss Sebastian who+ never gives in, explains German with more German. 


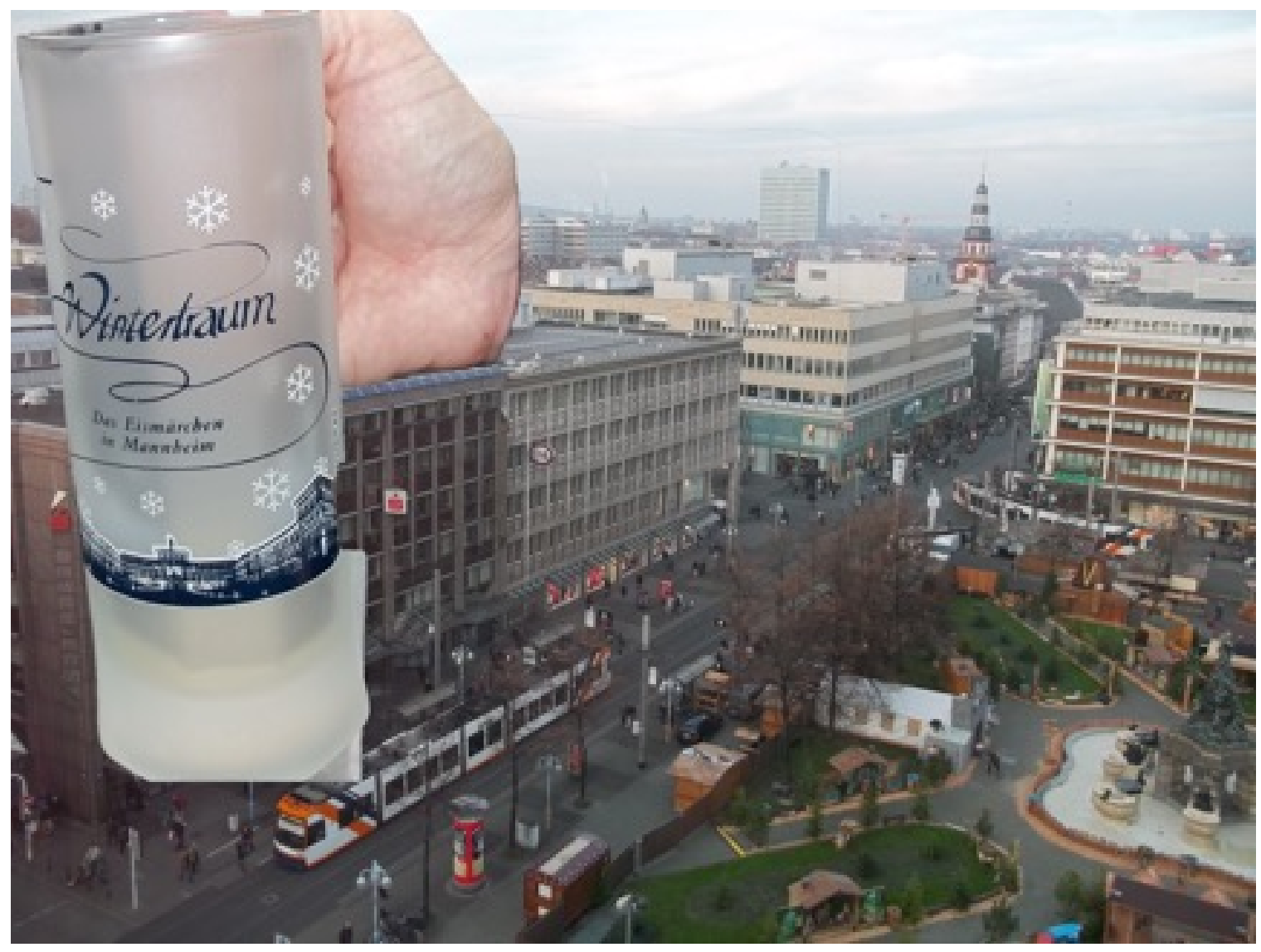

2. Die Angst (The Fear)

I never give in, explain German with more German:

This place is like a Wintertraum mit Grimm magic, not like boring Ohio where we only do mom-like chores and homework, and the dog gets ticks.

I try to be a real Mannheimer,

like when mein Kind weint und klagt

that "I miss my dog" and "you love Germany more than me," I speak a few words of Tratsch arrive 10 min early to meet my new German friend because I can't learn how to speak un-American and treat the locals to an echter Akzent as I burn through a walk in the city's alphabet street grid to become more German than the Germans. 


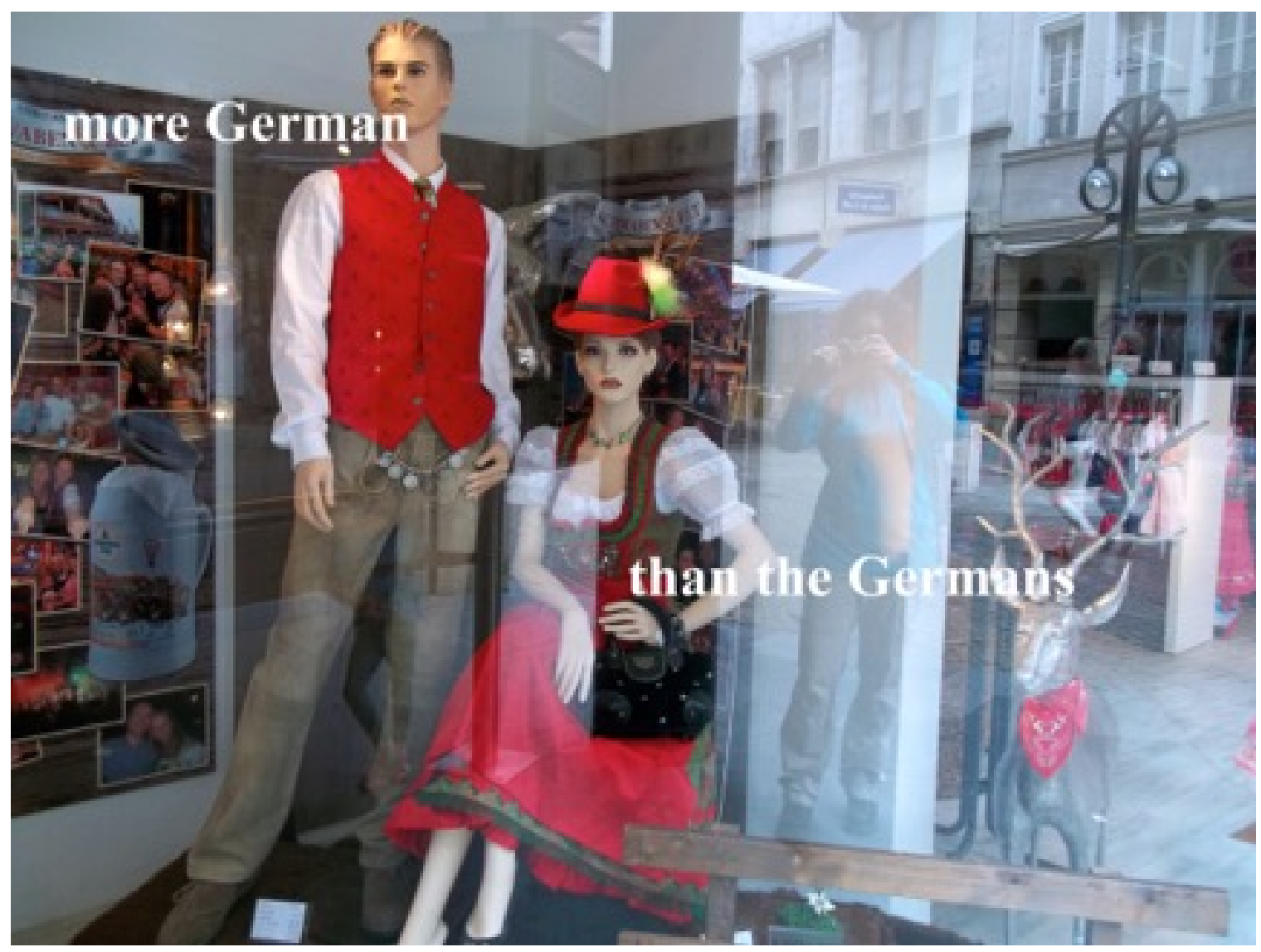

3. Der Stolz (The Pride)

I become more German than the Germans and don't feel Stolz in all of the American places, not about my verstehen in class, mein Kind or Mann who like that I can order their food in these spaces with Kellnerin draped in Dirndls und Lederhosen, Germans who are not proud of their nation or their selves but show pride in gut gemacht clothes that are more German than Germany. I get this feeling, share this fetish for all things Deutsch and Palatine, take my runs along the Rhein, go places no Mannheimer knows like Bacharach where we tourists creep along the winery vines like a tourist blight of red, white and blue as we dare to drink in all of these views. 


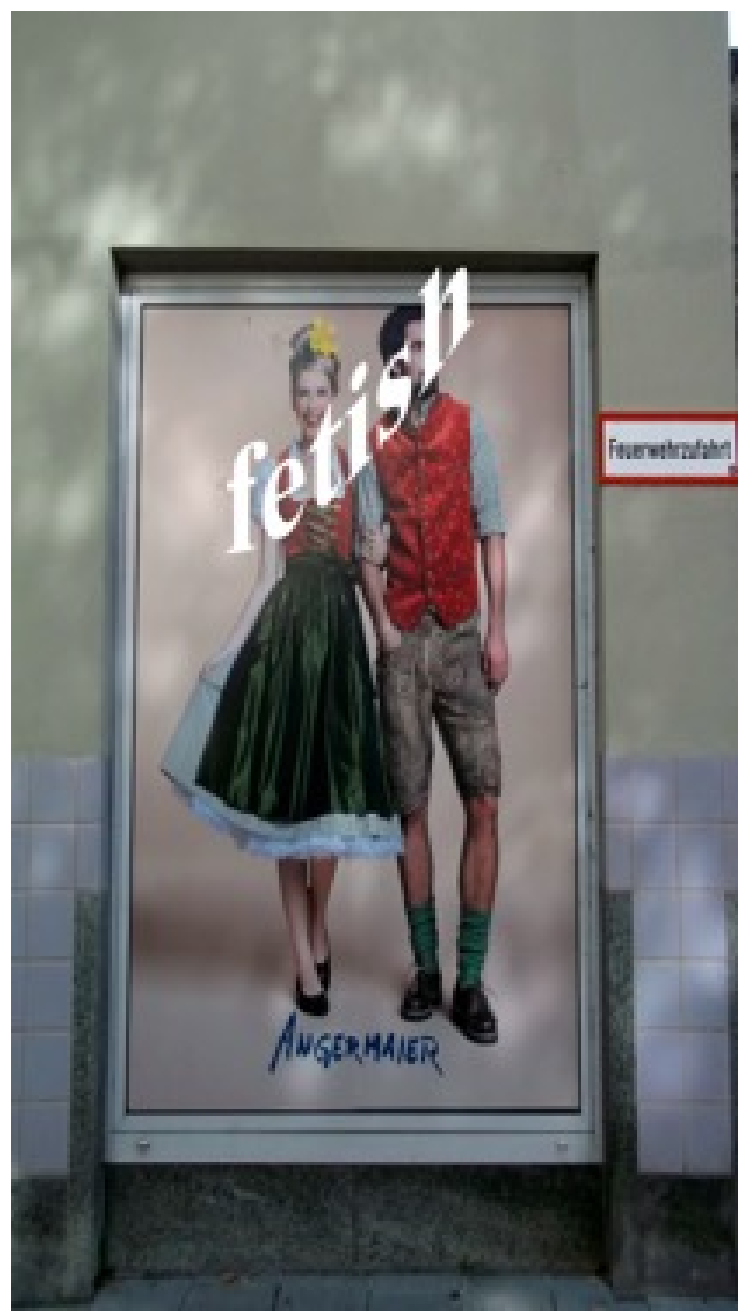

4. Der Ärger (The Annoyance)

Shop Windows, Mannheim

I dare to drink in all of these views-

windows with wispy women mannequins,

Dekolleté molded into Oktoberfest Dirndls,

hung over Lederhosen punked-out Männer,

displays more authentic than the Mannheimers

who sport suspenders and check-print shirts

around town, a glass of trockene Riesling in one hand,

a cigarette and a kid in the other, the dirty

smoke refracted onto the facades of shop fronts

and in my face as I stand and frown from the outside,

choke on the effluvium of cost and fashion

mutter that this is not Bavaria, outside

in English, my body warped in a hoodie,

hair frayed, jeans, disordered and strange. 


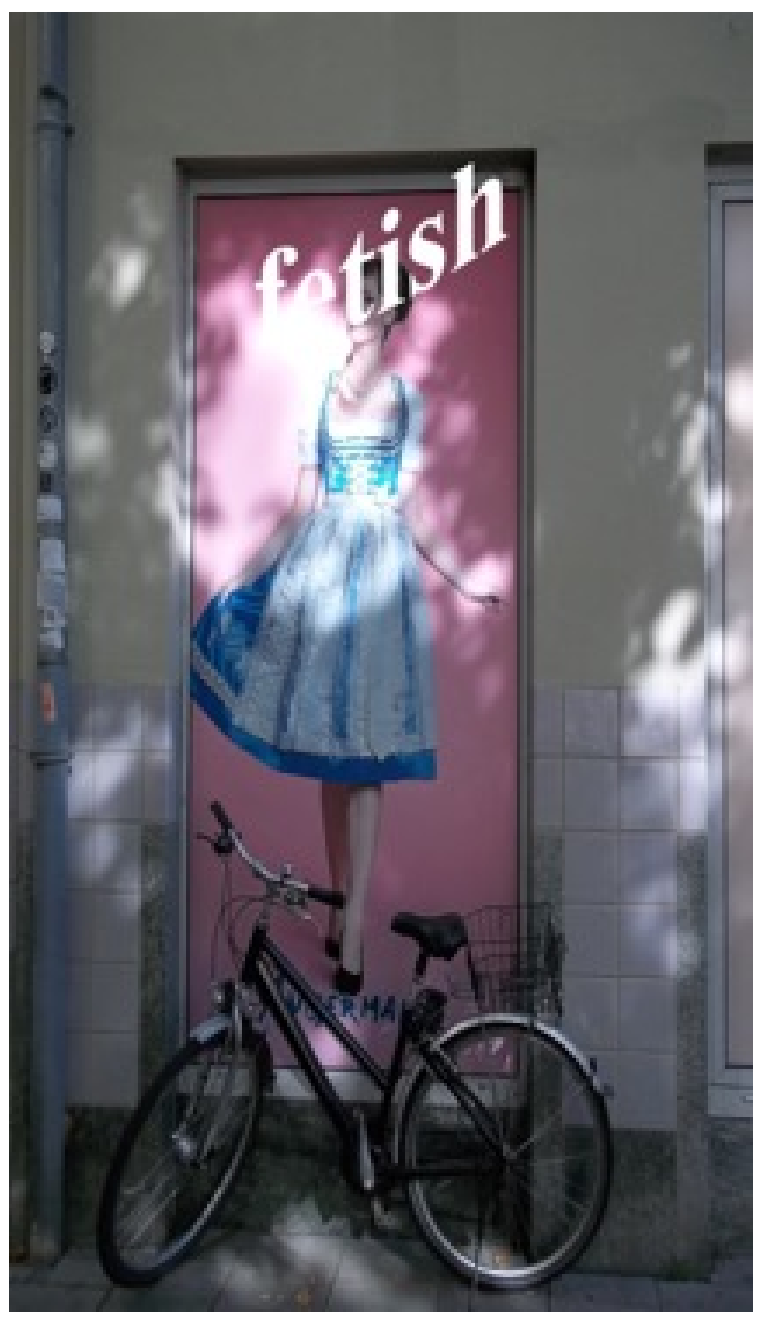

\section{Die (Un)Ordnung (The (Dis)Order)}

Disordered and strange, hair, jeans frayed,

I cannot bring mein Kind in order as we drag along the Mannheimer StraßeIst alles in Ordnung? Alles klar?she darts like an expert frogger onto the street and knocks a bicyclist off his pedestal into the corner as we snake our way to Kindergarten. Pass Auf! He yells (and not Ouf Pass! like a real Mannheimer). Watch out! I yell and pull her back to the sidewalk as the bicyclist turns and snips: Schlaf gut Kind! All of these Germans tell us how to keep order like the woman on the train platform who demands, Do you speak German? Because that man is taking video of your daughter. Her last words, as she points to a suited man with video-phone in hand, and turns away- 
And I thought you should know-

mean I must clamp the fun,

bringe alle in Ordnung with mein Kind

who moves time during Bahnstreiks

by tanzen like a kleine pied piper of chaos

knocking strangers off board

the train of forgotten rules.

In this series of five poems, I focused on embodiment in the experience of learning another language and engaging in culture through language (mis)acquisition in German language class, ordering food, holidays and the usual activities, and traveling with a middle-aged white female body and my kindergartner and male spouse.

White Feminism and White feminists. Sheila Squillante and I have been long time friends, writing collaborators, and feminist scholars and poets. Needing to make feminist art in response to the 2016 US presidential election, we engaged in a collaborative poetry project titled "Nasty Women Join the Hive" (Faulkner and Squillante 2018). I shared a poem about the inauguration. Sheila responded with a poem. I knit 12 pink pussy hats for our local Women's Marches ${ }^{\mathrm{TM}}$. We played a game of exquisite corpse with themes of a Trump presidency-rape culture, misogyny, locker room talk, feminist response-and then created a womanifesta with text, images, and sound that considered how an intersectional feminism can be realized with a hive metaphor. At first, we didn't recognize the critique of pussy hats as equating women's rights to white cis-gendered able-bodied women's vaginas, the hats as a representation of White privilege, "White women wearing pink hats and not acknowledging racism, body essentialism, and not listening to people of color, disabled, and trans* rights activists" (Faulkner and Squillante 2018, p. 168). We show our collaborative process in the following lines:

"Sheila and I keep talking. She tells me how things in the Pittsburgh march fell apart because of White women. There would be another march where White women were not centered, where pussy hats would not be visible.

We think about being White women. We think about being White feminists. We ask how we can be White Feminists without White Feminism. Fifty-three percent of Trump's vote was White women. This is our audience.

We ask. We start to listen. We invite other White feminists to listen. Then to act." (Faulkner and Squillante 2018, p. 168)

We remixed an intersectional approach to feminism and feminist identity through a womanifesta that uses video, images, and poetry to appeal to White feminists after reflecting on our own ignorance. We invite White feminists to decenter White women in our movements, to eradicate White feminism, and to leave our pink pussy hats home. We invite White feminists to reject White fragility and tears and to "just listen." "There can be empathy between people of color and progressive, sensitive, politically aware whites ... . We need to create poetry, art, research, and books that cannot be assimilated, but is accessible" (Anzaldúa [1992] 2013, p. 281). Our collaborative project is one answer to the call for accessible politically aware art. Poetic inquiry can be a good method for such projects and collaborations.

\section{Motherhood, Mothering, and Interpersonal Communication}

In addition to collaborative and political work, poetic inquiry offers a way to engage with the public-private dialectic to collapse the false dichotomy (Baxter 2011). Poetry's strength is the ability to position dialectics and refuse easy resolution. "A poem asserts itself as poetry by being in dialogue with what it resists" (Young 2010, p. 38). I have been using poetry in my scholarship and writing about mothering, motherhood, and feminism as a way to critique and resist middle-class White motherhood (Faulkner 2012a, 2014a, 2014b, 2017d, 2017e), marriage and the status quo (Faulkner 2016a), to show 
the interplay between the private and the public, and as a critical lens in the examination of family and interpersonal communication focusing on power structures (Suter 2018).

In the critical autoethnography, Bad Mom(my) Litany: Spanking Cultural Myths of Middle-Class Motherhood, I wrote about loving my child but abhorring the mother role by juxtaposing new motherhood experiences with being a relational scholar (Faulkner 2014b). I critique cultural advice and expectations of what being a good mother mean and use poetic inquiry to question entrenched myths about motherhood (Faulkner 2014b) as seen in the next poem.

\section{Instructions for Surviving Infant}

Remember the stubborn latch

clown purple mouth of gentian violet

your own face melted off

from exhaustion, say no thanks

to the $\mathrm{OB}$ at the 6-week cry

because you must remember

remember not to have another

do not get over it

do not cherish this

no taking something to ease your face

all ears that ear plugs can't stop up.

Forget which onesie you put

on the 9 week old you have to pick up,

panic when you must identify her

on the floor in the infant room

because all the white babies look alike

rows of drool encrusted chins

clumsy arms in the nursery

don't tell them her first sentence:

daddee needs more beer.

My super power means

even lactation consultants

are not safe from the arch of spray,

pure power, pure stubborn,

no bonding here

you contested and I persisted

like daughter like mother

give away the parent manuals

offer no cloak of citations.

When I was 7 weeks old

I went back to teach, to speed up

the insufferable infancy,

the mothering work I suck at.

Sit your boots in the chair

Baby Doo, Ms. Baby

first word: dog, ball, ockpuss

other first sentence: More cookie, please. (Faulkner 2015)

I use narrative and confessional poetry to question expectations about middle-class family life, the mother role as the most important, the expectation of mothering as self-abnegation, and the medical system as the expert in child rearing. 
This focus on the personal acts as an interrogation into the expectations of middle-class motherhood and the concomitant disappointments of never being good enough. I argue that the engagement with the embodied experiences of mothering can alter attitudes and create social change through the visibility of stigmatized identities (e.g., bisexual feminist, ambivalent mother) and the refusal to create false separations between the domestic and public. (Faulkner 2017d, p. 106)

In the poetry collection, Knit Four, Frog One (Faulkner 2014a), I wrote family narratives in different poetic forms (e.g., collages, free verse, dialogue poems, sonnets) to tell the stories of grandmother-mother-daughter relationships, women's work, mothering, family secrets, and patterns of communication in close relationships. I wrote and rewrote family stories to reveal patterns of interaction and to tell better stories and offer more possibilities. Feminist poet, Victoria Chang (2018) speaks to this potential in poetry.

Poems are like time machines. They travel through time as a medium for individual memory and, as a genre, they engage historical time, collective cultural memory. But I think poems also activate a simultaneity of past, present, and future. A poem's rhythm moves us forward in time; the imagination a poem (hopefully) sparks posits futurities, a constellation of potentialities. Considering the nexus of verb tenses versus the present tense of the reading experience, a poem has already happened, is always happening right now, and will soon happen again. (para. 12)

I incorporate dialectical thinking into the collection of family stories as verse to give voice to the both/and. For example, the following poem considers family trauma, pregnancy, coupling, and the everyday business of relationships as something more than a dichotomous private relating versus public persona choice.

\section{Make Two}

With two needles and a ball of string, we learn the art of multiplication-

2 couplets, lovers, dyads, pet rats, not twins like in my preggo horror movie.

Two tickets to a concert, a table for 2.

Not my favorite number-the rent is past due.

II, 2, two ways to write the number, my favorite curvy because you can lie

in the bottom, the bowl. The number of bites you need to share, a joint account. Two.

The usual number of cake layers, the pieces of toast you get with eggs, the \# of eggs

in the daily special, my good and bad side, dichotomy, either or (not both/and),

one part of a compound sentence. Two sides to the bed, two dimensions, two favorite colors,

the number of legs Dad once had, knit in front and back = M1, 2 stitches, what you need to erase a day, not the number after birth, 2 parts water, 2 ounces of bourbon. (Faulkner 2015) 
Mother-poems lay naked the taken-for-granted assumptions and social structures and stretch the binaries with a focus on personal family intimacies. In a series of collage poems composed from family artifacts, feminist research, and systematic recollections, I queer staid understandings of White middle-class mothering with MotherWork collages that are like a queer Pinterest scrapbook to "critique and interrogate expectations and attitudes about what mothers should do, think, and feel (e.g., see Figure 1). Good mothers in a pro-natalist culture should channel their creativity into things like making scrapbooks of their progeny. Spending time developing identities other than mother-such as poet, academic, and partner-makes fulfilling the normative role of the "good mother" impossible" (Faulkner 2017e).

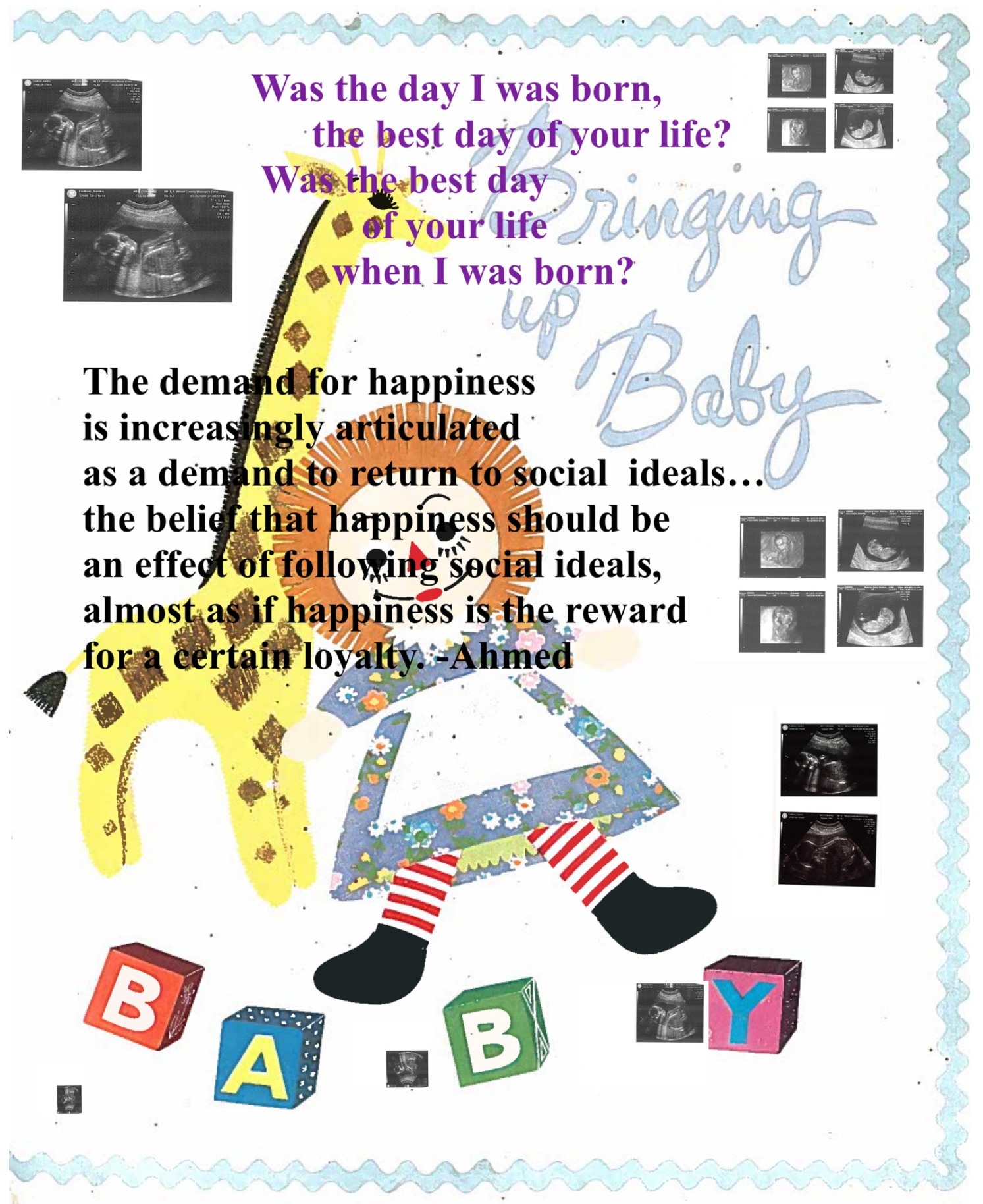

Figure 1. Bringing Up Baby. 
The feminist texts, poetry, images, and poetic analysis I used to create an alternative baby book engages with Halberstam's (1998) idea of scavenger methodology.

A queer methodology, in a way, is a scavenger methodology that uses different methods to collect and produce information on subjects who have been deliberately or accidentally excluded from traditional studies of human behavior. The queer methodology attempts to combine methods that are often cast as being at odds with each other, and it refuses the academic compulsion toward disciplinary coherence. (p. 13)

With MotherWork, a queer methodology is a feminist one. In a chapter on queering sexuality education in family and school (Faulkner 2018b), I use poetic collage as queer methodology by taking headlines of current events around women's reproductive health and justice, curriculum from liberal sexuality education, and conversations with my daughter about sex and sexuality to expand the idea of MotherWork and mother poems.

I engage with the meta-theoretical aspects of family talk about sex and sexuality education across seemingly disparate communication theory, models, and research traditions to allow broader understandings about communication and sexuality education than a reliance on one tradition provides: the use of my autoethnographic understandings of sexuality education in the form of dialogue with my daughter demonstrates reflexivity through the use of arts-based research methodology. The use of social science "research questions" to frame and push the poetic analysis shows critical engagement with literature on sexuality. The use of news headlines about sexuality connects personal experience about sexuality education to larger cultural issues. (Faulkner 2018b, p. 26)

\section{Poetry as Embodiment}

Perhaps the main reason I am drawn to poetry, is its ability to be embodied methodology. "I'm finally doing the research project I've thought about for years, and I don't give a shit if it fits into my academic program of research. I'm running toward the feminist ethnographer I want to be." I wrote these lines in a feminist ethnography on women and running that uses poetic inquiry to understand, describe, and query embodied experiences in everyday relational life, of which running and the interplay between physicality, emotional life, and intellectual life is a part for women who run (Faulkner 2018c, p. 38). In this project, I articulated on the page what I had been feeling, thinking, and doing the past decade when using poetry in my research and in my classroom. I cranked up the feminism through a two-and-a-half-year ethnography on women's embodied experiences of running-a poetic analysis of 41 interviews with women-identified runners, an autoethnography of my participation in the road races at the 2014 Gay Games, and a critical content analysis of web sites and blogs targeted toward women who run. I show poetic inquiry as a form of feminist embodied analysis through running as poetic practice and poetry as running logs. This meant the use of poetry as research analysis. This meant paying attention to "the smells and textures and bodily movements" in running to shift "away from discourse ... to include more emphasis on materiality" (Ellingson 2017, p. 83; Faulkner 2018c, p. 113).

I use poetry as ethnographic method. "Using poetry in an ethnographic project is a way to demonstrate anthropological insights, to tell a story about fieldwork through the telling, retelling, and framing of embodied experiences with a poetic sensibility" (Faulkner 2018c, p. 112). I use poetic inquiry - narrative poetry, haiku, poetic transcription, and poetic analysis—as feminist inquiry. Because my running practice is tied to my writing practice, I could not talk about a poetic analysis of women and running without talking about running and writing, running as poetic practice.

Writing is not a disembodied activity. Writing about running proved to be an embodied experience; I worked out structural, content, and theoretical issues as I ran. And my running became a problem to work out in my writing ... I can't pinpoint an exact moment when 
I recognized that poetic inquiry was the key to organizing and demonstrating this project as a feminist embodied ethnography. Most likely, the pieces were sweat out, sorted, and rearranged during runs. The problems of writing and running were tangled together for me in this project.

Writing Problems: How do I make running interesting to non-runners? How do I connect women's embodied experiences to the idea of running as a feminist act?

Running Problems: How do I keep running? How do I keep running despite my maladies? (Faulkner 2018c, p. 108)

Poetry can not only show embodiment, it can be an embodied experience.

The use of poems to help show what running feels like "becomes embodied experience when audiences feel with, rather than about a poem; they experience emotions and feelings in situ" (Faulkner 2017a, p. 226). Using poems about running can be an embodied experience for the audience "to have you feel like you are running with me and other women, to feel our gasps and intake of breath, to breathe in rhythm with the words" (Faulkner 2018c, p. 116). When I present this research and perform the poems, audience members tell me that they feel like they are running with me and my participants.

\section{Haiku as Running Log}

\section{Woman, Runner \\ a woman runner \\ is a woman who runs is \\ a woman runner}

\section{Cat Calls}

don't call us a girl

don't call us a girl jogger

fierce women running

Body is Mind

I am all body

aching arthritic hip feet

\section{PR: Personal Record}

\section{Run Body}

thunder with your thighs

running is like being born

saying yes to cheese

you become body

you become your body you

become your body

\section{Feminist Run}

Women Running

safety dressed in form

Caution: RUNNERS on the road

dogs cat call danger

keep run-run-running

run as strategy

physical mouthed resistance

strong-sweat out the shoulds

You are

if you run, you are

see yourself as a runner

athlete woman run.

(Faulkner n.d.) 
I used poetic inquiry, specifically haiku as field notes, found poetry and poetic transcription of interviews with women runners, and narrative poetry of my embodied experiences of running to demonstrate my analysis process, to show the rhythm of running, and to connect writing as embodiment to ethnographic practice.

In my field notes, I found poems. I wrote many entries in my field notes as poems, and constructed many poems while running. When I think about what makes poetry, I typically think of the line. "Poetry is the sound of language in lines ... Line is what distinguishes our experience of poetry as poetry, rather than some other kind of writing" (Longenbach 2008, p. xi). And when thinking of the line, I think of breath. For me, running is also about breath; breathing in the pleasure, breathing out the hurt. Breathing in who I want to be, breathing out lesser versions of self. Trying to breathe in through the nose and out through the mouth to catch my pace during a run. "The body is rooted in breath, rhythm, and poetry ... " (Snowber 2016, p. xv; Faulkner 2018c, p. 115)

"Poetry promises to return researchers back to the body in order to demonstrate how our theories arise out of embodied experience" (Faulkner 2017a, p. 214). The practice of poetic analysis-the use of poems as data for analysis-helped me to develop the form of the ethnography, which included visual, video, and sounds elements in a web-based public version of the ethnography (see Faulkner n.d.).

The sounds of running-the noise, the grunts, the breathing, the encouragement, the disappointment-jog you through training runs, races, and the in situ embodiment of a sport real women enjoy and loathe.

I hope you pace with us through the words, images, and sounds of women jogging, crying, raging, laughing, sprinting, and walking through their running lives. (Faulkner 2018c, p. 7)

This project represents a more physical feminism as I presented women's running experiences, highlighting their bodily experiences as connected to cultural practices through narrative, poetry, and poetic transcription; poetry as analysis, as representation, and as embodiment (McCaughey 1997; Velija et al. 2013). Physical Feminism focuses on the connection between physicality and consciousness by acknowledging "individuals' actual material bodies ... their everyday interactions with their bodies and through their bodies with the world around them" (Davis 1997, p. 15). The use of poetic inquiry expands "our understanding of ethnography by considering how we do embodiment" and how "our participants do embodiment" (Ellingson 2017, p. 81). Real Women Run paces readers through women's embodied running experiences; identities in motion, the inseparable mind-body connection, and running as social and solitary, pleasurable and painful, dangerous and empowering. "An embodied ethnography defies the mind-body split; a feminist ethnography pays attention to the material and the discursive by taking up emotional, physical, and ideological space." (Faulkner 2018c, p. 113).

\section{Sexual Harassment in the Academy}

Poetry can unmask hidden cultural assumptions, which is why it is valuable in activist projects. In my chapbook, Hello Kitty Goes to College (Faulkner 2012b), I wrote poetry about sexual harassment in the academy using the pop-culture character, Hello Kitty, as a way to examine taken for granted patterns of behavior. As Sara Ahmed (2017) writes, "making feminist points, antiracist points ... is about pointing out structures that many are invested in not recognizing" (p. 158). The series of poems portray administrative and faculty reactions to the standpoints of women of color, untenured women faculty, and students' experiences and narratives of harassment and hostile learning environments through fictionalized experiences of the cartoon character, Hello Kitty (Faulkner et al. 2009). The use of a fictional character is meant to have readers examine their implicit assumptions about academic life, because of the absurdity of a fictional character as student and professor. The poems in this chapbook were part of a research journal where I wrote about my experiences with sexual harassment at the university and fighting it through institutional channels. Poetry as feminist theory and praxis. 
To bring feminist theory home is to make feminism work in the places we live, the places we work. When we think of feminist theory as homework, the university too becomes something we work on as well as at. We use our particulars to challenge the universal. (Ahmed 2017, p. 10)

I wrote these poems to represent and analyze experiences of harassment, to critique the continued normalization of harassment by bringing the audience into the setting as participants through the evocation of the affective and cognitive feel of sexual harassment. The poetry in this collection shows how reactions to the presentation of standpoints are an important area to study for understanding how harassment is perpetuated and considered normal behavior in the university system. The series of poems follows Hello Kitty as she navigates the academy as an undergraduate student, transforms into a graduate student, and then transitions into a faculty member. The title poem sets up the scene where women are not viewed as learners and equally valued members of the academic community.

\section{Hello Kitty Goes to College}

\section{First Semester}

Her business professor stares at the red K sewn on the butt of her sweats as she slinks toward a desk in the front row. "My best work from the self-designed line" she confesses when he wants to know "why K?" in the hallway after supply chain class. He checks attendance during her group's talk on surplus stock. His voice makes her whiskers vibrate, the $\mathrm{K}$ on her top shrinks under his incessant gaze.

But this is just her professor she thinks. In lecture, he makes Tom and Jerry jokes, laughs at how the cat always gets into tight spots. HK considers she's the cat for the mouse, but she's just a student, this is just a joke. During office hours, her advisor tells her "Honey, professors are just bores with arrested development. Learn to fit the system, get your degree." HK takes this advice, enjoys the library with the stuffed couches and row after row of shelved books that smell like possibility. She feels smart and hip with her good grades and pledge to the honor society headed by her business professor.

II. HK Discovers She's Not White

When it gets colder on campus 
and snow piles around her dorm like used kitty litter, HK takes the bus to her only night class avoiding salty paws and snow ball fights with the freshmen boys who chant as she crosses the quad. Tonight, some men ride the bus and snicker "A.I." as HK pushes to the back of the bus to meet Keroppi and Jodie. She doesn't know what it means, talks of her new idea for school supplies. The outside bar voices continue, "Asian Invasion. Asian Invasion stop taking our scholarships."

HK wants to tell them she pays her way with her own body, her line of clothing. But her friends are faster. "Stupid Crackers. You can't even fill out your own applications." She just watches the green frog and orange dog shout back as the boys exit the bus.

III. The Visual Aid

On the power point slide, a leukemia-ridden cat cowers while doctors examine innards displayed on the metal exam table. HK pictures her own paws tied down with twine in the vet's office, licks between her claws when she hears the warning voicesSee what wearing no collar means? How hanging out with stray cats brings sickness to inchoate kittens?- But HK likes how they make their dens wherever they please, thinks them audacious and infinitely cool like some kind of queer po-mo cats. When she sees the picture blown up on the class screen and later taped up in the teaching assistant's office as an example of a great visual aid, her hair scratches her skin, she pants, overheated. When no one is watching she rips it off the wall, shreds it with her paws and pees on it, just in case. (Faulkner 2012b) 
In another poem, Hello Kitty experiences a difficult dissertation defense with work that calls out sexist practices and defies the standard status quo. Hello Kitty, speaking for women in the academy, learns that "when you speak as a feminist, you have to deal with strong reactions ... . Feminism is a sensible reaction to the injustices of the world, which we might register at first through our own experiences" (Ahmed 2017, p. 21).

Dissertation Abstracts International

Feminist Standpoint Theory: An Examination by a Post Modern Two-Dimensional Cat with No Mouth and 22,000 Products Bearing Her Image

Dr. H. Kitty had wanted to title her dissertation, Ode to the University, like a love letter to ideas, to chance and other marginal characters without traditional mouths or white teeth. Her committee balked: standpoint theory and self-narratives were quite enough. Other departments would question the methods, not tenure such love gut epistemology. During the defense, the token male member screamed her seminal argument was the "pissy cat position." HK wiped his spit off her whiskers with her camouflage hair bow, slipped a blank piece of paper down the conference room table. One by one, the members held the clean sheet as if it were a twisted student evaluation. Only the bisexual lesbian clapped, said Kitty's "right-on-response disallows the difficulty with our difference." HK considered ripping herself a mouth with her advisor's fountain pen, kicking the phantom pain in the teeth. Instead, she underlined new parts of her story with a Barbie highlighter, and let them pass her with their caveats and reservations. (Faulkner 2012b).

After getting a position at a university as a faculty member, Hello Kitty reflects on her continued work as a member in a sexist culture. "The danger of institutional sexism is that it allows us to judge and become complacent with someone else's experiences. Rather than allowing people who feel oppressed to own their stories, there is a need to discount them" (Ahmed 2017, p. 19).

\section{After the Faculty Meeting}

HK still believed in the academy though meetings like street brawls

left feminist cat scholar bodies piled in naked postmodern heaps beside her chair.

She believed even when she took her standpoint to the harassment advocate who chuckled,

told her to consider being spayed because it would help her emotionality-

even through stories of tenured professors having to rape in the middle of the quad in bright daylight with a metal weapon and maybe a drunken student party

before the possibility of firing would rise past a personnel meeting to the provost.

After all, many skillful eligible bachelors among their faculty deserved a date.

Jodie, the canine hire, howled through departmental dog jokes of chewed-up essays and sexy mailmen:

Why are dogs so obedient?

Because they sport choke collars.

Jodie started chanting in the copy room, 
Getting ass in your classes:

one semester's pay.

Being an ass to your colleagues:

one year's pay.

Getting a fair job:

impossible.

HK preferred the department's fresh talk

of cutting edge curriculums and saucy students

though the lecherous professor leered

through her working cats research talk,

asked her to retype the departmental notes

because her cat scratch made his eyes water.

Even then, she believed in her colleagues

and the idea of them wearing stripes and bows. (Faulkner 2012b)

In conclusion, the use of poetry in research practice offers us a way to engage in feminist methodology and pedagogy through collaborative work, reflexive engagement as feminist ethics, evocative critique and resistance of the status quo, and continued interplay of the private and public. Poetic Inquiry can be used with other methods like ethnography, interviews, and content analysis as a kind of constitutive scholarship (Manning 2014). We can use multiple methods to engage in "metatheoretical aspects of seemingly disparate communication and theory and models across contexts and research traditions to allow larger understandings about communication than a reliance on one tradition provides" (Faulkner 2016a, p. 12). We can represent our participant's stories in verse. We can demonstrate our reflexivity in lyrical lines. We can reframe our stories and our student's stories with fresh images. In my own work, poetic inquiry has created a more reflexive research process and feminist ethical practice. Even if you do not use poetry in your own research, poetic inquiry offers a feminist pedagogical practice that engages students and facilitates understanding and dialogue about important feminist issues. Poetic inquiry and poetry have a history of being used as feminist practice, theory, and pedagogy, and continue to offer a robust feminist methodological choice for our research, teaching, and praxis.

Funding: This research received no external funding.

Conflicts of Interest: The author declares no conflicts of interest.

\section{References}

Ahmed, Sara. 2017. Living a Feminist Life. Durham: Duke University.

Anzaldúa, Gloria. 2013. The new mestiza nation: A multicultural movement. In Feminist Theory Reader, Local and Global Perspectives. Edited by Carole R. McCann and Seung-Kyung Kim. New York: Routledge, pp. $277-84$. First published 1992.

Baxter, Leslie. 2011. Voicing Relationships: A Dialogic Perspective. Thousand Oaks: Sage.

Brady, Ivan. 2004. In defense of the sensual: Meaning construction in ethnography and poetics. Qualitative Inquiry 10: 622-44. [CrossRef]

Chang, Jennifer. 2018. "Each time the light changed": A Micro(inter)view with Jennifer Chang, curated by Lisa Olstein. Tupelo Quarterly. June 14. Available online: http:/ / www.tupeloquarterly.com/each-time-the-lightchanged-a-microinterview-with-jennifer-chang-curated-by-lisa-olstein/ (accessed on 14 June 2018).

Collins, Patricia Hill. 2000. Black Feminist Thought: Knowledge, Consciousness, and the Politics of Empowerment. New York: Routledge.

Davis, Kathy. 1997. Em-bodying theory: Beyond modernist and postmodernist readings of the body. In Embodied Practices: Feminist Perspectives on the Body. Edited by Kathy Davis. London: Sage, pp. 1-23.

Ellingson, Laura. 2017. Embodiment in Qualitative Research. New York: Routledge. 
Faulkner, Sandra L. 2005. Method: 6 poems. Qualitative Inquiry 11: 941-49. [CrossRef]

Faulkner, Sandra L. 2006. Reconstruction: LGBTQ and Jewish. International and Intercultural Communication Annual 29: 95-120.

Faulkner, Sandra L. 2009. Poetry as Method: Reporting Research through Verse. New York: Routledge.

Faulkner, Sandra L. 2012a. That Baby will Cost You: An intended ambivalent pregnancy. Qualitative Inquiry 18: 333-40. [CrossRef]

Faulkner, Sandra L. 2012b. Hello Kitty Goes to College: Poems. Chicago: Dancing Girl Press.

Faulkner, Sandra L. 2014a. Family Stories, Poetry, and Women's Work: Knit Four, Frog One (Poems). Rotterdam: Brill/Sense.

Faulkner, Sandra L. 2014b. Bad Mom(my) Litany: Spanking cultural myths of middle-class motherhood. Cultural Studies Critical Methodologies 14: 138-46. [CrossRef]

Faulkner, Sandra L. 2015. Knit Four, Make One: Poems. Somerville: Kattywompus Press.

Faulkner, Sandra L. 2016a. TEN: (The Promise of Arts-Based, Ethnographic, and Narrative Research in Critical Family Communication Research and Praxis. Journal of Family Communication 16: 9-15. [CrossRef]

Faulkner, Sandra L. 2016b. Postkarten aus Deutschland: A Chapbook of Ethnographic Poetry. Liminalities 12: 1.

Faulkner, Sandra L. 2017a. Poetic Inquiry: Poetry as/in/for Social Research. In The Handbook of Arts-Based Research. Edited by Patricia Leavy. New York: Guilford Press, pp. 208-30.

Faulkner, Sandra L. 2017b. Faulkner writes a middle-aged Ars Poetica. In Poetic Inquiries of Reflection and Renewal. Edited by Lynn Butler-Kisber, John J. Guiney Yallop, Mary Stewart and Sean Wiebe. Nova Scotia: MacIntyre Purcell Publishing Inc., pp. 147-52.

Faulkner, Sandra L. 2017c. Poetry is Politics: A Poetry Manifesto. International Review of Qualitative Research 10: 89-96. [CrossRef]

Faulkner, Sandra L. 2017d. Mother-Poems: Using the Confessional as Critique in Autoethnographic Poetry. In Creative Selves/Creative Cultures: Critical Autoethnography, Performance, and Pedagogy. Edited by Stacy Holman Jones and Marc Pruyn. Basingstoke: Palgrave-MacMillan.

Faulkner, Sandra L. 2017e. MotherWork Collage (A Queer Scrapbook). QED: A Journal in GLBTQ Worldmaking 4: 166-79. [CrossRef]

Faulkner, Sandra L. 2018a. Crank up the Feminism. Rise Up Review! Summer. Available online: www.riseupreview. com (accessed on 15 June 2018).

Faulkner, Sandra L. 2018b. Queering sexuality education in family and school. In Queering Families, Schooling Publics: Keywords. Edited by Anne M. Harris, Stacy Holman Jones, Sandra L. Faulkner and Eloise D. Brook. New York: Routledge, pp. 25-41.

Faulkner, Sandra L. 2018c. Real Women Run: Running as Feminist Embodiment. New York: Routledge.

Faulkner, Sandra L. n.d. Real Women Run: Running as Feminist Embodiment (Online Material). Available online: http:/ / innovativeethnographies.net/realwomenrun (accessed on 20 June 2018).

Faulkner, Sandra L., and Michael L. Hecht. 2011. The negotiation of closetable Identities: A Narrative Analysis of LGBTQ Jewish Identity. Journal of Social and Personal Relationships 28: 829-47. [CrossRef]

Faulkner, Sandra L., and Paul D. Ruby. 2015. Feminist identity in romantic relationships: A relational dialectics analysis of email discourse as collaborative found poetry. Women's Studies in Communication 38: 206-26. [CrossRef]

Faulkner, Sandra L., and Sheila Squillante. 2018. Nasty Women Join the Hive: A Womanifesto Invitation for White Feminists. 1. Vol. 40. Prod. Women \& Language Online. Available online: https:/ / www.womenandlanguage. org/40-1 (accessed on 15 June 2018).

Faulkner, Sandra L., Bernadette M. Calafell, and Diane S. Grimes. 2009. Hello Kitty Goes to College: Poems about Harassment in the Academy. In Poetic Inquiry: Vibrant Voices in the Social Sciences. Edited by Pauline Sameshima, Monica Prendergast and Carleton Derek Leggo. Rotterdam: Brill/Sense, pp. 187-208.

Grasso, Samantha. 2018. Art Student Delivers Perfect Response to Teacher's Request to 'Dial Back the Feminism'. The Daily Dot. February 8. Available online: https://www.dailydot.com/irl/dial-down-the-feminism/ (accessed on 8 February 2018).

Halberstam, Judith. 1998. Female Masculinity. Durham: Duke University.

Hirshfield, Jane. 1997. Nine Gates: Entering the Mind of Poetry. New York: Harper Collins.

Krizek, Robert L. 2003. Ethnography as the excavation of personal narrative. In Expressions of Ethnography: Novel Approaches to Qualitative Methods. Edited by Robin P. Clair. Albnay: SUNY, pp. 141-51.

Longenbach, James. 2008. The Art of the Poetic Line. Minneapolis: Graywolf Press. 
Manning, Jimmie. 2014. A constitutive approach to interpersonal communication. Communication Studies 65: 432-40. [CrossRef]

Manning, Jimmie, and Adrianne Kunkel. 2015. Qualitative approaches to dyadic data analyses in family communication research: An invited essay. Journal of Family Communication 15: 185-92. [CrossRef]

McCaughey, Martha. 1997. Real Knockouts: The Physical Feminism of Women's Self-Defence. New York: New York City Press.

Moraga, Cheris, and Glora Anzaldúa. 1981. This Bridge Called My Back: Writings by Radical Women of Color. Edited by Cheris Moraga and Glora Anzaldúa. New York: Kitchen Table.

Olesen, Virginia. 2005. Early millennial feminist qualitative research. In The Sage Handbook of Qualitative Research. Edited by von Norman K. Denzin and Yvonna S. Lincoln. Thousand Oaks: Sage Publications, pp. 235-78.

Poetry Foundation. 2012. Adrienne Rich: 1929-2012. Poetry Foundation. Available online: https://www. poetryfoundation.org/poets / adrienne-rich (accessed on 20 June 2018).

Reed, T. V. 2013. The poetic is political: Feminist poetry and the poetics of women's rights. In Feminist Theory Reader, Local and Global Perspectives. Edited by Carole R. McCann and Seung-Kyung Kim. New York: Routledge, pp. 85-97. First published 2005.

Reilly, Rosemary C., Virginia Lee, Kate Laux, and Andréanne Robitaille. 2018. Using found poetry to illuminate the existential and posttraumatic growth of women with breast cancer engaging in art therapy. Qualitative Research in Psychology 15: 196-217. [CrossRef]

Richardson, Laurel. 1997. Fields of Play: Constructing an Academic Life. New Brunswick: Rutgers.

Snowber, Celeste. 2016. Embodied Inquiry: Writing, Living and Being Through the Body. Rotterdam: Brill/Sense.

Strine, Mary S. 1989. The politics of asking women's questions: Voice and value in the poetry of Adrienne Rich. Text and Performance Quarterly 9: 24-41. [CrossRef]

Suter, Elizabeth A. 2018. The promise of contrapuntal and intersectional methods for advancing critical interpersonal and family communication. Communication Monographs 85: 123-39. [CrossRef]

Velija, Philippa, Mark Mierzwinski, and Laura Fortune. 2013. "It made me feel powerful": Women's gendered embodiment and physical empowerment in the martial arts. Leisure Studies 32: 524-41. [CrossRef]

Young, Dean. 2010. The Art of Recklessness: Poetry as Assertive Force and Contradiction. Minneapolis: Graywolf Press.

(C) 2018 by the author. Licensee MDPI, Basel, Switzerland. This article is an open access article distributed under the terms and conditions of the Creative Commons Attribution (CC BY) license (http:/ / creativecommons.org/licenses/by/4.0/). 